\title{
SEJARAH PERKEMBANGAN INTERNET dan KEBUTUHAN INFORMASI ERA ONLINE DALAM DUNIA PENDIDIKAN
}

\author{
Sumargono \\ Jurusan Matematika Sains Fakultas MIPA \\ Universitas Pesantren Tinggi Darul Ulum Jombang
}

\begin{abstract}
Abstraksi
Internet pada mulainya digunakan hanya sebatas keperluan militer sekitar pertengahan abad 19. Tetapi dengan kemajuan hardwere dan software zaman sekarang internet menjadi kebutuhan primer, utama dan penting dalam segala bidang, kususnya dunia pendidikan. Dewasa ini seluruh aspek kehidupan tersentuh oleh dunia digital internet online, karena dengan adanya pekerjaan akan lebih mudah dan cepat selesai mempercepat waktu dan meningkatkan keefektifan danefisiensi. Disamping kelebihan yang dapat diperoleh dari intenet online informasi disajikan berupa digital buku-buku yang berjilid-jilid dapat disimpan dalam bentuk file yang cukup dimuat dalam sekeping CD-ROM. Dengan demikian pada saat ini internet online adalah kebutuhan akan menjadi kebutuhan primer dalam dunia pendidikan.
\end{abstract}

Dunia pendidikan telah mulai bergeser dari sekolah/universitas tradisional menjadi sekolah/universitas e-education. Hal ini merupakan pengaruh positif dari informasi online. Berbagai penelitian menunjukkan adanya kontribusi signifikan dari informasi online pendidikan terhadap akselerasi pengembangan IPTEK. Hal ini ditunjukan anatara lain oleh tingginya frekwensi rujukan paper ilimiah online, cepatnya perkembangan bidang bioinformatika yang memanfaatkan internet secara optimal untuk bertukar data dan hasil observasi. Walaupun pada pelaksanaannya masih ada kelemahan dan kendala dalam hal sekuriti, hak cipta dll. Tetapi proses meng-online-kan informasi ini merupakan etape yang harus kita lalui untuk memajukan pendidikan, dan sekolah/universitas online dan riset di indonesia.

Keywords: Internet, pendidikan, militer, e-education, IPTEK.

\section{PENDAHULUAN}

Internet pada awalnya dikembangkan AS pada pertengahan abad 19, dan semula dipergunakan sebatas untuk keperluan militer. Pada dewasa ini di negara maju, internet hampir menjadi kebutuhan primer. Layanan yang ditawarkan internet pun semakin lengkap, komunikatif dan memanjakan konsumen dalam arti akses internet. Teknologi ADSL (asymmetric Digital Subscriber Line) yang populer beberapa tahun belakangan ini membuat internet menjadi kebutuhan yang dapat dinikmati akses internet 24 jam.

Pada masa awal, pemakaian internet hanya tebatas untuk berkirim electronic mail, WWW (Word Wide Web) mulai popular digunakan sekitar awal abad 90-an, dengan memakai berbagai Web browser seperti Nescape, internet explorer, dsb. Seiring dengan perkembangan 
hardwere maupun softwere yang pesatdan cepat, maka materi yang disampaikankan lewat web internet mengalami perkembangan sangat pesat. Materi yang dibuat tidak terbatas berupa teks, melainkan gambar, suara, vidio, streming, hingga yang bersifat interaktif, seperti chatting, vidio converence, dan lain sbagainya.

\section{SEJARAH INTERNET}

PERKEMBANGAN

Pada sekitar tahun 1957 Dephan AS DoD (Departement of Defense) membentuk ARPA (Advanced Research Projects Agency) sebagai tanggapan terhadap peluncuran Sputnik-nya Uni Sovyet. ARPA bertugas meningkatkan Hal ini dimungkinkan karena kemajuan teknoligi dibidang hardware dan software, sebagaimana yang diramalkan oleh Gordon Moore (Moor's Law), bahwa kemampuan kerja komputer akan berlipat dua kali dalam 18 bulan. Dapat dikatakan bahwa informasi yang sampai kepada kita mengalami beberapa pengubahan format. Informasi dan ilmu pengetahuan yang selalu biasa didokumentasikan dan dikomunikasikan secara manual, sekarang ditransfer dalam bentuk digital. Sehingga tulisan ilmiah populer, artkel, skripsi, tesis, disertasi telah umum disimpan dalam format elektronik (misalnya format word, PDF, dsb), pada disket, CD ROM ataupun DVD. Karena tipis, ringan, sangat mudah bagi kita untuk membawa informasi itu kemana-mana disamping itu sangat mudah di copy atau digandakan.

Selanjutnya kemajuan yang dicapai oleh teknologi internet tersebut membuat informasi dapat ditampilkan di web internet atau dikirim lewat e-mail, sehingga dapat diakses dari berbagai penjuru dunia. Syaratnya hanya satu yaitu online internet. Keywords pada bagian akhir proses ini adalah "online" yaitu suatu informasi di dunia cyber, yang pada akhirnya turut memberikan akselerasi terhadap pengembangan ilmu pengetahuan dan teknologi modern.

kemampuan teknologi yang dapat dimanfaatkan oleh militer. Sebenarnya ARPA tidak memiliki ahli ilmu pengetahuan ataupun laboratorium. Yang dimiliki hanya kantor dan budget kecil (bagi standar Pentagon) saja. ARPA menjalankan tugasnya dengan memberikan bantuan dan melakukan kontrak kerja dengan universitas-universitas dan perusahaanperusahaan yang memiliki ide yang dianggap menjanjikan bagi operasinya.

Pada pertengahan tahun 1960-an, saat puncak Perang Dingin, DoD ingin memiliki komando dan pengendalian jaringan yang dapat mempertahankan diri bila terjadi perang nuklir. Jaringan telepon tradisional dianggap tidak aman. Karena bila satu jalur saja hilang, maka hal ini dapat mengakibatkan terhentinya semua percakapan yang menggunakan jaringan atau bahkan yang hanya menggunakan sebagian jaringan secara tiba-tiba. Untuk mengatasi masalah ini DoD mengubah arah risetnya, ARPA. Bekerjasama dengan beberapa universitas, ARPA memutuskan bahwa jaringan yang diperlukan DoD adalah berbentuk packetswitching yang terdiri dari sebuah subnet dan komputer-komputer host. Pada Desember 1968, ARPA memberikan kontraknya kepada BBN, sebuah biro konsultan di Cambridge, Massachusetts untuk membangun jaringan 
tersebut dan membuat software-software pendukung.

Walaupun pada masa itu masih terdapat kekurangan pada masalah software, dan hardwere, tetapi sejak tahun 1969 berhasil diluncurkan sebuah jaringan eksperimen yang menghubungkan empat buah simpul yaitu UCLA, UCSB, SRI dan UTAH University. Keempat simpul ini memang memiliki berbagai kontrak dengan ARPA, dan masing-masing simpul mempunyai komputer host yang benarbenar berbeda dan tidak bersesuaian satu dengan lainnya. Jaringan ini disebut ARPANET dan segera setelah itu berkembang dengan pesat meliputi seluruh wilayah AS dalam tiga tahun pertamanya ARPANET dikembangkan.

Sebagai tambahan dalam membantu pertumbuhan ARPANET yang masih prematur ini, ARPA juga membiayai penelitian jaringan satelit dan jaringan radio paket yang mobile. Percobaan ini juga menunjukkan bahwa protokol-protokol ARPANET yang telah ada tidak sesuai untuk dioperasikan pada jaringan ganda. Pengamatan ini mendorong semakin banyaknya penelitian tentang protokol, yang berpuncak pada penemuan model dan protokol TCP/IP. TCP/IP secara spesifik dirancang untuk menangani komunikasi melalui internetwork, sesuatu yang menjadi semakin penting dengan semakin banyaknya jaringan dan LAN yang dihubungkan ke ARPANET.

Untuk mendorong pemakaian protokol-protokol baru tersebut, ARPANET mengadakan beberapa kontrak dengan BBN dan Universitas California di Berkeley untuk mengintegrasikan protokolprotokol tersebut ke dalam Berkeley UNIX. Para peneliti di Berkeley menyusun sebuah program antarmuka (interface) ke jaringan (socket) yang memudahkan dan menulis beberapa program utilitas, aplikasi dan manajemen untuk membuat sistem jaringan lebih mudah dioperasikan.

Pada tahun 1983, ARPANET memiliki jaringan yang besar dan sudah dapat dianggap stabil dan sukses. Sampai pada keadaan ini, ARPANET menyerahkan manajemen jaringan ke Defense Communication Agency (DCA) untuk menjalankan ARPANET sebagai jaringan operasional. Yang pertama dilakukan DCA adalah memisahkan bagian jaringan militer ke subnet tersendiri, MILNET, yang memiliki gateway-gateway yang sangat ketat membedakan antara MILNET dengan sisa subnet riset lainnya.

Selama tahun 1980-an, jaringan-jaringan tambahan, khususnya LAN, makin banyak yang dihubungkan ke ARPANET. Sejalan dengan bertambah luasnya jaringan, host-pun semakin mahal. Karena itu DNS (Domain Naming System) dibentuk untuk mengorganisasi mesin ke dalam domain-domain tertentu dan memetakan nama-nama host ke dalam alamatalamat IP. Sejak itu, DNS menjadi sistem database yang tergeneralisasi dan terdistribusi untuk menyimpan berbagai informasi yang berhubungan dengan penamaan modal penelitian. Pada tahun 1990, ARPANET telah tersusun oleh jaringan-jaringan yang baru, yang sebenarnya dilahirkan sendiri oleh ARPANET. Setelah itu ARPANET menghentikan operasinya dan dibongkar. Sampai saat ini, MILNET masih tetap beroperasi.

Selanjutnya NSFNET, Pada akhir tahun 1970an, NSF (National Science Foundation) melihat 
begitu besarnya dampak ARPANET bagi penelitian universitas. Namun hanya universitas yang memiliki kontrak penelitian dengan DoD yang dapat bergabung ke ARPANET. Kekurangan akses yang universal ini mendorong NSF untuk membangun sebuah jaringan maya, CSNET. Pada tahun 1984 NSF mulai merancang jaringan backbone berkecepatan tinggi yang akan menghubungkan keenam pusat superkomputernya di San Diego, Boulder, Champaign, Pittsburgh, Ithaca dan Princeton. Jaringan ini diproyeksikan sebagai pengganti ARPANET dan akan dibuka untuk seluruh kelompok-kelompok riset universitas, laboratorium riset, perpustakaan dan musium untuk mengakses keenam superkomputernya itu dan berkomunikasi satu dengan lainnya. Jaringan ini juga terhubung dengan ARPANET.

Jaringan NSFNET segera meraih sukses dalam waktu yang relatif singkat dan sekaligus kelebihan beban. Selanjutnya NSF dengan segera membuat rencana jaringan penerusnya dan memberikan kontrak kepada konsorsium Michigan-based MERIT untuk melaksanakan rencana tersebut. Jaringan ini pun akhirnya kewalahan sehingga pada tahun 1990 jaringan ini segera ditingkatkan kemampuannya. Seiring dengan perkembangan berkelanjutan, NSF menyadari bahwa pemerintah tidak dapat memberikan dana pengembangan jaringan untuk selamanya. Selain banyak organisasi komersial yang ingin bergabung ke dalam jaringan yang dibiayai NSF. Akibatnya, NSF meminta MERIT, MCI dan IBM untuk membentuk perusahaan nirlaba, ANS (Advanced Networks Services). Pada tahun 1990, ANS mengambil alih NSFNET dan meningkatkan kemampuan jaringan itu untuk membentuk ANSNET.
Sehingga Pada tahun 1991, Wakil Presiden AS Al Gore, mengusulkan perluasan arsitektur NSFNET agar melibatkan sekolah K-12, community college (perguruan tinggi setempat), dan college dua-tahun lebih banyak lagi. Desember 1991, Kongres AS mengesahkan rancangan undang-undang NREN (National Research and Educational Network) yang dapat diakses oleh pelaku bisnis dengan mengizinkan mereka membeli sebagian dari jaringan untuk penggunaan komersial. Tetapi Pada tahun 1995, backbone NSFNET tidak diperlukan lagi untuk menginterkoneksikan jaringan-jaringan regional NSF. Hal ini disebabkan karena banyak perusahaan yang mengoperasikan jaringan IP komersial. Pada saat ANSNET dijual ke America Online pada tahun 1995, jaringan regional harus keluar dan harus memiliki layanan IP komersial untuk dapat saling terhubung.

Kemudian untuk mempermudah dan meyakinkan bahwa setiap jaringan regional dapat berkomunikasi dengan jaringan regional lainnya, NSF memberikan kontrak kerja kepada empat operator jaringan untuk membuat NAP (Network Access Point). Operator-operator tersebut adalah PacBell (San Francisco), Ameritech (Chicago), MFS (Washington D.C.) dan Sprint (New York City). Setiap operator jaringan yang ingin menyediakan layanan backbone kepada jaringan-jaringan regional NSF harus menghubungkan semua NAP tersebut. Selain NAP-NAP NSF, juga telah dibuat bermacam-macam NAP pemerintah (misalnya, FIX-E, FIX-W, MAE-East dan MAE-West) dan NAP-NAP komersial (misalnya CIX). 
ke Internet. Pada waktu yang lampau

Seiring dengan perkembangan internet di Amerika Serikan, maka Negara-negara dan daerah lainnya juga membangun jaringan yang sebanding dengan NSFNET. Di Eropa misalnya, EuropaNet merupakan sebuah backbone IP untuk organisasi-organisasi riset dan EBONE merupakan jaringan yang lebih berorientasi komersial. Keduanya jaringan ini menghubungkan sejumlah kota di Eropa. Setiap negara di Eropa memiliki satu atau lebih jaringan nasional yang sebanding dengan jaringan regional NSF.

Setelah TCP/IP dinyatakan sebagai satu-satunya protokol resmi pada 1 januari 1983, jumlah jaringan, mesin dan pengguna yang terhubung ke ARPANET bertambah dengan pesatnya. Pada saat NSFNET dan ARPANET saling dihubungkan, pertumbuhannya menjadi eksponensial. Banyak jaringan regional yang bergabung dan hubungan-hubungan dibuat untuk membangun jaringan di Kanada, Eropa dan Pasifik. Pada pertengahan tahun 1980-an, orang mulai memandang kumpulan jaringanjaringan tersebut sebagai sebuah internet, dan kemudian disebut Internet. Pertumbuhan terus berlanjut secara eksponensial, dan pada tahun 1990 Internet telah tumbuh menjadi 3000 jaringan dan 200.000 komputer. Pada tahun 1992, host kesatu-juta telah terhubung ke jaringan. Pada tahun 1995, terdapat banyak backbone, ratusan jaringan tingkat menengah (regional), puluhan ribu LAN, jutaan host dan puluhan juta pengguna.

Faktor yang mempunyai andil besar dalam pertumbuhan yang cepat itu adalah penyambungan jaringan-jaringan yang telah ada penyambungan tersebut meliputi SPAN (jaringan fisika luar angkasa NASA), HEPNET (jaringan fisika energi tinggi), BITNET (jaringan mainframe IBM), EARN (jaringan akademis Eropa), dan jaringan-jaringan lainnya. Sejumlah link trans atlantik juga terbentuk. Dengan perkembangan yang eksponensial ini, cara informal lama dalam mengoperasikan Internet tidak lagi dipakai. Pada bulan Januari 1992, Masyarakat Internet (Internet Society) terbentuk. Masyarakat Internet bertujuan untuk mempromosikan manfaat Internet.

Dengan demikian sejak awal tahun 1990-an, Internet banyak dipakai oleh para akademisi, pemerintah dan para peneliti industri. Sebuah aplikasi baru, WWW (World Wide Web) mengubah wajah Internet dan membantu jutaan pengguna baru, nonakademisi ke jaringan. Aplikasi ini, ditemukan oleh fisikawan CERN Tim Berners-Lee, tanpa mengubah fasilitasfasilitas yang telah ada namun membuatnya menjadi lebih mudah digunakan. Bersama-sama dengan Mosaic viewer, yang dibuat oleh NCSA (National Center for Supercomputer Applications), WWW memungkinkan sebuah situs (site) untuk menyusun sejumlah halaman informasi yang berisi teks, gambar, suara dan bahkan video, dengan meletakkan link ke halaman-halaman lainnya. Dengan meng-klik sebuah link, pengguna akan segera dibawa ke halaman yang ditunjukkan oleh link tersebut. Dalam setahun setelah Mosaic diluncurkan, jumlah server WWW berkembang dari 100 menjadi 7000. Pertumbuhan yang cepat ini terus berlangsung dengan pesat sampai sekarang. 


\section{AKSES INFORMASI ONLINE \\ INTERNET DALAM DUNIA PENDIDIKAN}

Internet yang sekarang sangat terkenal sebagai sebuah sistem jaringan dan komunikasi yang jelajahnya tidak terbatas telah menjadi kebutuhan manusia. Dalam dunia pendidikan komunitas akademik maupun non akademik dewasa ini telah terbiasa melakukan komunikasi lewat internet. Seperti diskusi, konsultasi, proses pelajar jarak jauh, pengiriman artikel, pengiriman tugas kuliah, ujian online, pemesanan buku, pnegiriman data onservise, dan berbagai aktifitas lain pendidikan dan pengajaran dapat dilakukan dari sebuah PC yang terkoneksi ke jaringan internet. Akses informasi pendidikan dan pembelajaran dapat dilakukan kapan saja, siapa saja, dimana saja, ini telah memberikan informasi online yang sigmnifikan terhadap berkembangan ilmu pengetahuan dan teknologi kususnya didalam dunia pendidikan.

Perpustakaan online meruapakan sumber literatur utama bagi seseorang peneliti dan pendidik untuk mengikuti perkembangan bidang ilmu yang ditekuninya. Sebagian besar waktu dihabiskan untuk mebaca jurnal ilmiah, laporan penelitian, seminar yang tersedia dalam bentuk buku online (E-book). Dan dapat melalui perpustakaan online. Hal yang paling sulit adalah bagaimana memilih informasi yang diperlukan diantari ribuan atau jutaan halaman yang tersedia, padahal waktu yang ada sangat terbatas. Masalah ini dapat dipecahkan apabila jurnal, laporan, buku dan informasi lain yang dicari tersebut berada dalam format elektronik (misalnaya format PDF, Word, postcript dsb.), sehingga dapat diakses online melalui internet. Misalnya situs journal IEEE (http://www.ieee.org), PubMed, dll. Dengan adanya sumber online, peneliti dan pendidik lebih mudah mencari literatur dan informasi terbaru dalam bidangnya.

Pada masa sekarang ada layanan mempermudah memilih informasi online yang diperlukan, yaitu searching engine di internet. Yang sangat populer adalah http://google.com dam http://yahoo.com. Situs searching engine lain seperti http://vivisimo.com memiliki kelebihan dengan mengelompokkan hasil searching kedalam beberapa group (cluster), menurut Keywords dari situs tersebut. Tersedianya informasi di internet dan semakin canggihnya alat pencari membuat peneliti menjadi lebih cepat dalam mencari informasi yang diperlukan.

Dari contoh diatas dapat disimpulkan bahwa usaha meng-online-kan informasi memiliki beberapa manfaat penting, antara lain:

1. Artikel ilmiah dimuat secara online, memiliki potensi akses yang lebih besar dan lebih sering dipakai sebagai rujukan.

2. Semakin kuatnya kesempatan akses pada suatu informasi, pada gilirannya dapat memberikan feedback positif bagi pemilik awal informasi tersebut.

3. Data dan informasi yang dimuat secara online dapat membantu akselerasi perkembangan suatu cabang ilmu pengetahuan baru.

4. Para ahli pendidikan dapat mengembangkan sistem belajar online internet.

Usaha meng-online-kan informasi pendidikan dalam proses belajar, ini tidak hanya dilakukan 
oleh negara maju. Komunitas di Indonesia tidak ketinggalan dalam memanfaatkan teknologi internet untuk meng-online-kan informasi dalam dunia pendidikan dan penelitian. Bebrapa usaha yang telah dilakukan antara lain:

\section{Edukasi Online}

Aktifitas yang sering disebut dengan elearning atau e-education, kini telah memanfaatkan internet sebagai wahana belajar mengajar. Bebrapa diantaranya adalah situs berita iptek (http://beritaiptek.com ) yang memuat berita ilmu pengetahuan dan teknologi dalam bahasa indonesia, situs ilmukomputer.com yang mendapat penghargaan international WSIS award dari PBB, dan situs lain yang belakangan ini semakin menjemur. Ada juga IBU teledukasi, www.ibuteledukasi.com. Yang seja pertengahan 2002 telah menawarkan konsep belajar jarak jauh dengan media internet.

e-Education merupakan suatu istilah yang digunakan untuk memberi nama pada kegiatan-kegiatan pendidikan dan pengajaran yang wajib dilakukan melalui akses online internet. Melalui internet seakan-akan sekolah atau kampus dapat membuka kelas di berbagai lokasi di seluruh dunia, karena para siswa-siswi atau mahasiswamahasiswinya dari berbagai belahan dunia dapat langsung mengakses situs Web internet e-education dan mengikuti pendidikan dan pengajaran hanya dara PC yang berada didepannya. Disaping itu peserta didik dapat berkomunikasi secara langsung online selama 24 jam, tanpa birokrasi yang rumit.

Ada banyak manfaat yang dapat dipetik dari e-education baik oleh lembaga pendidikan maupun peserta didik dan masyarakat pada umumnya.

Manfaat bagi lembaga pendidikan sekolah/universitas:

a. Memperpendek jarak belajar mengajar.

b. Memperluas pasar tidak dibatasi lokasi.

c. Memperluas jaringan mitra kerja dalam dan luar negeri.

d. Biaya pendidikan terkendali menjadi murah dan bisa dijangkau sesuai kebutuhan.

e. Banyak penghematan karena semua aktivitas pendidikan dilakukan secara online.

f. Cash flow terjamin, dengan eeducation ini lembaga akan menerima pembayaran terlebih dahulu sebelum mengirim materi pembelajaran yang dipesan siswa/mahasiswa.

g. Cara e-education meningkatkan citra lembaga, layanan pendidikan, menyederhanakan proses, mempermudah akses, fleksibelitas tinggi, dan meningkatkan efisiensi.

2. Digital Library

Salah satu contoh adalah http://greendigitalpress.com. Usaha ini dirintis oleh Arief Budi Witarto dan Romi Satria Wahono, keduanya peneliti di LIPI. Ide awal proyek ini berasal dari keinginan mewujudkan perpustakaan digital Indonesia. Yang 
dapat diakses online diinternet. Contoh dari situs serupa di dinia adalah situ PubMed (http://pubmed.com ) di bidang biomedik, atau situs CiteSeer.IST

(http://citeser.ist.psu.edu ) di bidang computer, yang menyediakan ribuan artikel ilmiah dalam format elektronik (fotmat PDF) kontribusi dari seluruh dunia. Situs digital library ini memuat abstraksi publiksi khusus di Indonesia (peper \&paten). Hal ini akan memberikan kemudahan akses bagi peneliti lain dan mempercepat proses komunikasi komunitas ilmia Indonesia. Proyek yang lebih besar saat ini yang sedang dirintis adalah pembangunan Indonesia Digital Library Network (IDLN) yang diharapkan mampu menghubungkan seluruh perpustakaan yang dimiliki lembaga pendidikan baik sekolah dasar, sekolah menengah maupun universitas, yang dikelola negeri maupun swasta menjadi IDLN bersekala Nasional. Untuk membangun sistem e-library tersebut telah tercipta sejumlah sofwre seperti CDS dan ISIS. Sementara itu juga telah terbentuk komunitas pemerhati dan pengelola perpustakaan seperti

pustakawan@itb.ac.id milik ITB

3. Diskusi ilmiah lewat mailing list (disingkat milis)

Mailing list adalah forum diskusi yang langsung lewat electonic mail. Bebrapa komunitas ilmiah seperti IECI (Indonesia Society on Electical, Electronics Comunication \& Information), HFI (Himpunan Fisika
Indonesia) biotek-indonesia.net. telah memiliki forum diskusi sendiri. Pada milis yang aktif, secara reguler diadakan seminar online. Salah satu peserta mempresentasikan penelitiannya. Dan perta yang lain mengajukan pertanyaan atau memberikan masukan, lewat email, selain presentasi penelitian, konsultasi masalah, kegiatan lain misalnya resensi paper penelitian yang tebaru.

\section{MASALAH YANG TIMBUL SAAT MENG-ONLINE-KAN INFORMSI}

Semakin banyaknya informasi tersedia secara online, memberikan efek positif bagi kegiatan pendidikan dan pembelajaran, pendidikan dan penelitian. Namun hal ini tidak terlepas dari berbagai kendala yang perlu diwaspdai oleh pengguna internet e-education Sekuriti. Masalah utama pemakai internet adalah security. Serangan virus, spamming mail merupakan ancaman pertama begitu kita online di internet. Virus dapat menghampus data di hard disk, merusak file penelitian dan mencuri informasi pribadi.

1. Hak cipta

Tulisan ilmiah yang di buat online seringkali dijiplak oleh pihak lain tanpa seizin pemeiliknya. Kalimat-kalimat pada suatu artikel dikutip tanpa menyebutkan referensi asalnya. Ada juga pihak tak bertanggung jawab yang memakai material di internat, tapi menghampus nama pengarangnya, atau sumber asli artikel tersebut. Seolaholah artikel itu adalah karyanya sendiri. Hal-hal ini dapat dikategorikan kejahatan intelektual, dan merugikan penulis asli tulisan tersebut. 
2. Kendala teknis untuk artikel yang hanya tersedia versi cetak

Tidak semua jurnal tersedia dalam bentuk elektronik. Terutama untuk artikel yang diterbitkan sebelum tahun 1990, seringkali hanya tersedia versi cetak. Misalnya jurnal ilmiah IEEE Trans. On Pattern Analysis and Machine Intelligence (PAMI), kalau dilihat di situs http://www.computer.org/tpami hanya menyediakan versi elektronik mulai tahun 1988. artikel-artikel yang sudah tua juga masih tersedia dalam wujud "atom", yaitu berupa kertas. Tapi dewasa ini, sudah banyak dijual scaner yang mampu men-scan satu halaman dokumen dalam waktu kurang dari 1 detik, dan langsung dikonversikan ke format PDF. Misalnya "ScanSnap" produk fujitsu, yang sudah termasuk di dalamnya software Adobe Acrobat untuk mengkoversikan hasil scan ke dalam format PDF. Selain masalah tersebut masih banyak hal-hal lain yang perlu diperhatikan dalam meng-online-kan informasi. Resiko memang ada. Tapi hal itu memang harus kita lewati untuk mencapai kemajuan. No risk, No gain.

\section{RANGKUMAN}

Internet pada mulainya digunakan hanya sebatas keperluan militer sekitar pertengahan abad 19. Tetapi dengan kemajuan hardwere dan software zaman sekarang internet menjadi kebutuhan primer, utama dan penting dalam segala bidang, kususnya dunia pendidikan. Dewasa ini seluruh aspek kehidupan tersentuh oleh dunia digital internet online, karena dengan adanya pekerjaan akan lebih mudah dan cepat selesai mempercepat waktu dan meningkatkan keefektifan danefisiensi. Disamping kelebihan yang dapat diperoleh dari intenet online informasi disajikan berupa digital buku-buku yang berjilid-jilid dapat disimpan dalam bentuk file yang cukup dimuat dalam sekeping CDROM. Dengan demikian pada saat ini internet online adalah kebutuhan akan menjadi kebutuhan primer dalam dunia pendidikan.

Dunia pendidikan telah mulai bergeser dari sekolah/universitas tradisional menjadi sekolah/universitas e-education. Hal ini merupakan pengaruh positif dari informasi online. Berbagai penelitian menunjukkan adanya kontribusi signifikan dari informasi online pendidikan terhadap akselerasi pengembangan IPTEK. Hal ini ditunjukan anatara lain oleh tingginya frekwensi rujukan paper ilimiah online, cepatnya perkembangan bidang bioinformatika yang memanfaatkan internet secara optimal untuk bertukar data dan hasil observasi. Walaupun pada pelaksanaannya masih ada kelemahan dan kendala dalam hal sekuriti, hak cipta dll. Tetapi proses mengonline-kan informasi ini merupakan etape yang harus kita lalui untuk memajukan pendidikan, dan sekolah/universitas online dan riset di indonesia.

\section{DAFTAR PUSTAKA}

McLeod, Raymond. 2001. Management Information System. Edisi 9. Upper saddle River. Pearson Prentice Hall.

Sillaggan, Iwan. 2001. Amankah Melakukan Transaksi Online. Chip Computer. 
Kalakota, Ravi and Marcia Robinson. 2002. E-

Business : Roadmap for Success. Addison

Wesley Longman. Inc.

Junaidi Utomo. 2002. Strategi Implementasi

Teknologi untuk mendukung Peningkatan

Kinerja Perusahaan. Buletin Jendela

Informatika vol 1 Nomer 4.

Kenneth E. Kendall and Julie E. Kendall. 2002.

System Analysis and Design, Fifth Edition.

Prentice Hall.

J. Supranto, M.A. 2001. Pengukuran Tingkat Kepuasan Pelanggan. Jakarta : Rineka Cipta.

Sutedjo, Budi. 2001. Perspektif e-Business,

Tinjauan Teknis Manajerial dan Strategi. Jakarta: Andi Offset.

Sutedjo, Budi. 2007. e-Educational Konsep, teknologi dan aplikasi internet Pendidikan. Jakarta : Andi Offset.

O'Brien, A, James. 2004. Management Information System: Managing Information Technology in The Internetworked Enterprise. Sixth Edition. Irwin McGraw Hill.

Steve Lawrence, 2001. Online or Invisible Nature. http://citese 
